\title{
SECURITIES REGULATION: SEC BRANDS SALES REWARD INTERPOSITIONING A BREACH OF FIDUCIARY DUTY AND ANTIFRAUD VIOLATION
}

Delaware Management Company ${ }^{1}$ extends the antifraud provisions of the securities acts to eliminate a heretofore common mutual fund practice, the interpositioning of a broker-dealer, now deemed by the Securities and Exchange Commission to be a fraudulent breach of fiduciary duties. Delaware Management Company, the investment adviser and principal underwriter for two mutual funds, interposed Mutual Funds Associates, Incorporated, a retail broker of fund shares, between the funds and the best market in the purchasing of over-the-counter securities for the funds' portfolios. Purchasing from Associates rather than directly from the wholesale market caused the funds to incur additional brokerage fees in excess of $\$ 200,000$ over a five-year period. Management allowed this interpositioning to reward Associates for its efforts in making retail sales of the mutual funds' shares. Management's profits as adviser-underwriter were increased by the additional fund share sales, but the funds themselves did not profit significantly from such sales increases, since the ratio of assets per share, and thus the book value of each share, was not enhanced. ${ }^{2}$ The Commission found that Management and its officers, who also served as officers of the funds, breached their fiduciary duty in violation of the antifraud provisions of the securities acts. The Commission, however, did not clearly indicate whether the officers' breach occurred in their capacity as investment advisers or as corporate officers, raising again the question faced in O'Neill v. Maytag. ${ }^{3}$

The problems of interpositioning and another sales reward called the "give up"-an order by a fund to its purchasing broker to relinquish part of his commission to a fund share retailer-were brought to light by recent congressional reports dealing with mutual funds. ${ }^{4}$ The sales reward originated on the New York Stock Ex-

' CCH Fed. SEc. L. ReP. I 77,458 (SEC Exchange Act Release No. 8128, July 19, 1967).

2Id. at 82,886. See generally H.R. REP. No. 2337, 89th Cong., 2d Sess. 172 (1966).

3339 F.2d 764 (2d Cir. 1964). See also 50 CoRnell L.Q. 545 (1965).

- H.R. REP. No. 2337, supra note 2; H.R. Doc. No. 95, pts. 2, 4, 88th Cong., 1st Sess. (1963); H.R. Doc. No. 2274, 87th Cong., 2d Sess. (1962). 
change where a minimum commission rate is required. ${ }^{5}$ Since exchange brokers will transact the large fund purchases at less than the rate required by exchange rules, management companies order the excess to be paid out in "give ups" to fund share retailers. On the exchange, this practice does not injure the funds since they are charged the minimum rate anyway, but injury does occur in the over-thecounter market, where there is no minimum rate. When interpositioning or a "give up" occurs in the over-the-counter market, it is reasonable to assume that the fund is paying excessive brokerage fees, and thereby wasting assets, since brokers are given commissions for unnecessary or unrelated services, or are given a "padded" amount with the understanding that part must be given up. The Commission has given considerable attention to these practices in its recent studies, ${ }^{8}$ but Delaware marks the initial use of the antifraud provisions in controlling such abuses. The Commission found violations of the three major antifraud provisions, section 17 (a) of the Securities Act, ${ }^{7}$ which authorizes administrative and injunctive action and is directed toward sellers; section $10^{8}$ and Rule $10 \mathrm{~b}-5^{9}$ under the Securities Exchange Act, which have been interpreted to provide civil remedies ${ }^{10}$ and are directed toward purchasers and sellers; and section 206 of the Investment Advisers Act, ${ }^{11}$ which is specifically directed at the regulation of advisers. These provisions employ similar langauge, essentially forbidding the use of any device, scheme, artifice, practice, or course of business which would operate as a fraud in the purchase and sale of securities.

The antifraud provisions have been broadly construed to protect the investor, and elements constituting fraud under the acts have not been limited to the strict common law requirements ${ }^{12}$ of misrepresentation or falsehood, scienter, justifiable reliance, proximate cause, and injury. ${ }^{13}$ Half-truths, omissions, and nondisclosures

\footnotetext{
5 N.Y. Stock Exchange Const. art. XV, appearing in $2 \mathrm{CCH}$ NEw YoRk Stock ExchaNge Guide q1 1701-12.

- See note 4 supra.

' Securities Act of $1933 \$ 17$ (a), 15 U.S.C. $\$ 77 q$ (1964).

${ }^{8}$ Securities Exchange Act of $1934 \$ 10,15$ U.S.C. $\$ 78$ j (1964).

- 17 C.F.R. \$240.10h-5 (1967).

${ }^{10}$ See, e.g., Kardon v. National Gypsum Co., 69 F. Supp. 512 (E.D. Pa. 1946).

11 Investment Advisers Act $\$ 206,15$ U.S.C. $\$ 80 \mathrm{~b}-6$ (1964).

13 See, e.g., SEC v. Van Horn, 371 F.2d 181 (7th Cir. 1966); Stevens v. Vowell, 343 F.2d

374 (10th Cir. 1965). See also 3 L. Loss, Securities Regulation 1430.44 (2d ed. 1961).

${ }^{13}$ See generally W. Prosser, The LAw OF TORTs $\S \S 101-105$ (3d ed. 1964).
} 
have all been termed fraud under the acts, ${ }^{14}$ as has the typical interpositioning arrangement in which the broker or adviser profits directly from the client's payment of excess brokerage fees either by interpositioning himself or by requiring a "kick-back" from an interposed third party. ${ }^{15}$ As a general rule, the antifraud provisions have not been applied to breaches of fiduciary duty by corporate officers in the purchase or sale of the corporation's securities unless the element of deceit was present. ${ }^{18}$ The Commission and the courts, however, have consistently held that a breach of the fiduciary duty owed a client by his investment adviser or broker is a special situation and does constitute an antifraud violation under the acts. ${ }^{17}$ In SEC v. Capital Gains Research Bureau, Incorporated,,$^{18}$ the United States Supreme Court noted that "equitable" fraud is sufficient to satisfy the antifraud provisions, and that a breach of the fiduciary duty which Congress recognized in its passage of the Investment Advisers Act constituted such equitable fraud. ${ }^{19}$ Indeed, in $O^{\prime} N e i l l$ v. Maytag, ${ }^{20}$ the principal decision holding that breaches of corporate fiduciary duty without deceit are not antifraud violations, the court specified that the duty of a broker or advisor to his client was not under consideration, and that a breach of this duty might well constitute actionable fraud under Rule 10b-5.21

In Delaware the SEC found that the officers involved owed a duty to the mutual funds to seek the most advantageous transactions for the funds' portfolios, and that Management, as adviser, had a simliar responsibility. The Commission held that both Management and the officers breached their fiduciary duties by interposing Associates, and that this breach constituted a "fraud upon the funds and

\footnotetext{
14 See, e.g., Hughes v. SEC, 174 F.2d 969 (D.C. Cir. 1949).

${ }^{15}$ See, e.g., Archer v. SEC, 133 F.2d 795 (8th Cir.), cert. denied, 319 U.S. 767 (1943); H. C. Keister \& Co., CCH FEd. SEc. L. REP. I 77,414 (SEC Exchange Act Release No. 7988, Nov. 1, 1966).

${ }^{16}$ O'Neill v. Maytag, 339 F.2d 764 (2d Cir. 1964); Schoenbaum v. Firstbrook, 268 F. Supp. 385 (S.D.N.Y. 1967). See generally 51 VA. L. REv. 508 (1965).

${ }_{17}$ See Hughes v. SEC, 174 F.2d 969 (D.C. Cir. 1949); Thomas Brown III, CCH FED. SEC. L. REP. $\llbracket 77,430$ (SEC Exchange Act Release No. 8032, Feb. 8, 1967); H. C. Keister \& Co., CCH Fed. SEc. L. REp. I 77,414 (SEC Exchange Act Release No. 7988, Nov. 1, 1966).

${ }^{18} 375$ U.S. 180 (1963).

${ }^{10} I d$. at 194 .

20339 F.2d 764 (2d Cir. 1964).

${ }^{21} \mathrm{Id}$. at 768.
} 
their shareholders"22 in violation of the antifraud provisions of the securities acts. The use of a broker-dealer to execute transactions on behalf of the funds in securities in which that broker-dealer did not make a market was found to constitute a course of conduct prohibited under the acts. The Commission further determined that the incurring of unnecessary brokerage fees and the transaction of purchases at a sum exceeding the most favorable price were fraudulent, since both were incompatible with the letter and spirit of the funds' policies stated in their prospectuses. Consequently, the prospectuses were held to be materially false and misleading. Pursuant to its acceptance of an offer of settlement in which Management agreed to reimburse the funds and Management and Associates consented to abide by the Commission's findings, the SEC temporarily suspended the registrations of the two firms, and suspended the officers from association with any broker-dealer for periods of up to 60 days.

Because the Commission did not clearly indicate in which of their two capacities the officers were found to be perpetrating the fraud, the holding in the Delaware case lends itself to more than one interpretation. The Commission may have found the fraud to exist only in the breach of the duty owed the funds by Management and its officers in their capacity as investment brokers and advisers. This interpretation is in keeping with the "equitable" fraud theory advanced by the Supreme Court in Capital Gains, and does not conflict with the recent cases requiring more than a general breach of corporate responsibility to sustain a fraud allegation under the securities acts. If this were its rationale, the Commission has curtailed an abusive fund practice while remaining within the established limits of the provisions designed to prevent fraud. The Commission, however, may also have found fraud in the breach of fiduciary responsibility owed the fund corporations by their officers. The Commission placed some emphasis on the dual capacity in which the officers were serving, ${ }^{23}$ but the parties' service as corporate officers of the funds assumes relevance only if viewed as the source of fiduciary duties in addition to those owed as brokers or advisers. Reliance upon a breach of the officers' duty to their corporation would represent a marked departure from the recent cases holding

\footnotetext{
22 CCH FED. SEC. L. REP. at 82,886 .

${ }^{22}$ Id. at 82,884 .
} 
that a general breach of fiduciary responsibility does not constitute fraud under the acts. Such a departure would serve to extend the Commission's power, without congressional authorization, into the area of corporate regulation traditionally left to the states. Commentators have suggested that the regulation of fiduciary duties, as well as procedural questions such as an appropriate statute of limitations, could better be handled through new federal legislation, rather than an expansive interpretation of the existing securities laws. ${ }^{24}$ Finally, it is possible that the Commission found that actual deceit was present, reasoning that the funds, as corporate entities, were the victims of deception, and were not to be charged with the knowledge of their officers. ${ }^{25}$ Such a finding would indicate a tacit rejection of the doctrine of imputed knowledge, ${ }^{26}$ since the interlocked fund officers had full knowledge of the improper practices.

In addition to its potential impact on securities law, the Delaware decision may significantly alter mutual fund practices. The Commission's holding that three antifraud provisions were violated suggests a desire to provide multiple remedies against interpositioning and "give ups." The need for Commission action to restrict sales reward abuses cannot be questioned. However, the elimination of these practices from the over-the-counter market, while permitting them to continue on the exchange because of its minimum commission rate, appears to place over-the-counter dealers at an unfair disadvantage in competition for mutual fund portfolio business. A better approach would be to eliminate the abusive practices at their source; i.e., force reduction of the exchange's minimum commission rate for large volume purchases and thus eliminate excess fees available for distribution as sales rewards. This fee adjustment would go far to remove the temptation confronting the mutual fund management companies to divert fund assets to their own advantage, and would preclude the development of still more intricate procedures to circumvent the Commission's ruling in the instant case. ${ }^{27}$

${ }^{24}$ See Ruder, Pitfalls in the Development of Federal Law of Corporations by Implication Through Rule 10b-5, 59 Nw. U.L. Rev. 185 (1964); 50 CoRNell L.Q. 545 (1965); 51 VA. L. REV. 508 (1965).

${ }^{25}$ See Ruckle v. Roto Am. Corp., 339 F.2d 24 (2d Cir. 1964); Heilbrunn v. Hanover Equities Corp., 259 F. Supp. 936 (S.D.N.Y. 1966).

${ }^{26}$ See generally 3 W. Fletcher, Cyclopedia of the Law of Private Corporations $\S 824$ (1965).

${ }^{27}$ See H.R. REP. No. 2337, supra note 2, at 187. 